\title{
Haemodynamic effects of frusemide in patients suspected of having acute myocardial infarction
}

\author{
Harry Mond, ${ }^{1}$ David Hunt, and Graeme Sloman \\ With the technical assistance of Jayne Ramshaw and Jan Spokes \\ From the Cardiology Department, Royal Melbourne Hospital, Victoria, Australia
}

The haemodynamic effects of intravenous and intramuscular injections of $40 \mathrm{mg}$ frusemide were studied in 17 patients with suspected acute myocardial infarction. Sixteen of the patients had either clinical or radiographic evidence of left ventricular dysfunction. There was an average diuresis of $710 \mathrm{ml}$ during the 60 minutes after the injection. Haemodynamic data were obtained before and at 15,30, and 60 minutes after the injection.

Sixty minutes after the intravenous injection there were significant falls in the pulmonary artery diastolic pressure $(P<0.001)$, pulmonary arterial wedge mean pressure $(P<0.005)$, cardiac output $(P<0.05)$, and stroke volume $(P<0.005)$. There was also a significant rise in the peripheral vascular resistance at 30 minutes $(P<0.005)$. No significant alterations occurred in the right atrial pressure, arterial systolic pressure, heart rate, or pulmonary arterial and systemic arterial oxygen saturations.

Sixty minutes after the intramuscular injection, a significant fall occurred in the pulmonary artery diastolic $(P<0.02)$ pressure together with a significant rise in the peripheral vascular resistance $(P<0.05)$. There was an insignificant fall in the cardiac output and stroke volume, and for this reason the intramuscular route of administration is preferred.

Ventricular function curves constructed by plotting the cardiac output against the pulmonary arterial wedge pressure suggested that the heart, after an acute myocardial infarction, responds to a diuresis along the ascending limb of the function curve. Discretion should be exercised in the use of potent parenteral diuretics where the severity of left ventricular dysfunction is uncertain. The left ventricular filling pressure, reflected through the pulmonary artery diastolic pressure or the pulmonary arterial wedge pressure, may be used as a guide to therapy.

Until recently, the evaluation of myocardial performance after acute myocardial infarction has been limited to the assessment of the clinical signs, chest radiographs, and other noninvasive procedures (Fowler, 1968; Tattersfield et al., 1969; Karliner and Ross, I97I ; Dowling, Sloman, and Urquhart, 1971). With the introduction of haemodynamic studies, it has been shown that left ventricular dysfunction is common after acute myocardial infarction (Fluck et al., 1967; Rackley and Russell, 1972), and that the classical clinical and radiographic signs thought to represent cardiac decompensation are in many cases late in appearing or resolving, and misleading or difficult to interpret, thus hindering any rational timing of therapy (Sjogren, 1970; Lassers et al., 1970; McHugh et al., 1970; Rutherford, McCann, and O'Donovan, 1971; McDonald and

Received 7 May 1973.

1 National Heart Foundation of Australia Grant-in-Aid G.480.
McDonald, 1972; Mond, Hunt, and Sloman, 1973b).

The use of diuretic agents after acute myocardial infarction has been said to be safe and effective (Stock, 1970), but little is known of the haemodynamic effects of the potent diuretic agent frusemide (Lasix). It is a rapidly acting diuretic that may lead to excessive plasma water loss, hypotension, and shock (Wolk, Scheidt, and Killip, 1972), and these actions may be particularly hazardous after acute myocardial infarction. Despite this, and the problems of excessive potassium loss, intravenous frusemide has been suggested as a routine after a myocardial infarction irrespective of the presence or absence of clinical evidence of left ventricular dysfunction (Stock, 1970).

In this study a comparison is made of the haemodynamic effects of intravenous and intramuscular injections of $40 \mathrm{mg}$ frusemide, in 17 patients ad- 
TABLE I Clinical features of patients studied and urine output with intravenous and intramuscular frusemide

\begin{tabular}{|c|c|c|c|c|c|c|c|}
\hline $\begin{array}{l}\text { Case } \\
\text { No. }\end{array}$ & $\begin{array}{l}\text { Age and } \\
\text { sex }\end{array}$ & Infarction & $\begin{array}{l}\text { Pulmonary } \\
\text { crepitations }\end{array}$ & $\begin{array}{l}\text { Atrial } \\
\text { sound }\end{array}$ & $\begin{array}{l}\text { Pulmonary venous } \\
\text { congestion on } \\
\text { radiograph }\end{array}$ & Drugs & $\begin{array}{l}\text { Urine } \\
\text { output }(m l)\end{array}$ \\
\hline \multicolumn{8}{|c|}{ Intravenous frusemide } \\
\hline $\mathbf{I}$ & $43 M$ & Anterior infarction & + & + & + & & 1000 \\
\hline 2 & $59 M$ & Possible infarction & + & + & - & $\begin{array}{l}\text { Atropine during } \\
\text { study }\end{array}$ & 540 \\
\hline 3 & $50 \mathrm{M}$ & Possible infarction & + & - & - & On digoxin & 400 \\
\hline 4 & $66 \mathrm{M}$ & $\begin{array}{l}\text { No change ECG; raised } \\
\text { enzymes }\end{array}$ & + & - & + & & 745 \\
\hline 5 & $59 M$ & Anterior infarction & + & + & + & On procainamide & 590 \\
\hline 6 & $48 M$ & Anterior infarction & + & + & + & & 1200 \\
\hline 7 & $54 M$ & LBBB ; raised enzymes & + & - & + & & 1300 \\
\hline 8 & $48 \mathrm{M}$ & Subendocardial infarction & - & - & + & & 600 \\
\hline 9 & $53 M$ & Anterior infarction & + & + & + & & 630 \\
\hline \multirow[t]{2}{*}{10} & $38 \mathrm{M}$ & Inferior infarction & - & - & - & & 700 \\
\hline & & & & & & Mean urine output & $770 \mathrm{ml}$ \\
\hline \multicolumn{8}{|c|}{ Intramuscular frusemide } \\
\hline I I & $49 \mathrm{~F}$ & Subendocardial infarction & + & - & + & & I450 \\
\hline 12 & $49 M$ & Subendocardial infarction & - & - & + & & 1680 \\
\hline 13 & $42 M$ & Inferior infarction & + & - & + & $\begin{array}{l}\text { Lignocaine during } \\
\text { study }\end{array}$ & 1000 \\
\hline 14 & $45 M$ & Anterior infarction & + & + & - & & 900 \\
\hline 15 & $60 M$ & Possible infarction & + & - & - & & 550 \\
\hline 16 & $60 M$ & Anterior infarction & + & - & + & & 500 \\
\hline \multirow[t]{2}{*}{17} & $59 \mathrm{~F}$ & Subendocardial infarction & + & - & - & $\begin{array}{l}\text { Intranasal oxygen } \\
\text { during study }\end{array}$ & 300 \\
\hline & & & & & & Mean urine output & $910 \mathrm{ml}$ \\
\hline
\end{tabular}

mitted to a coronary care unit with symptoms suggestive of acute myocardial infarction. The aim was to include patients who, after an acute myocardial infarction, might be treated in a coronary care unit with parenteral frusemide on the basis of clinical or radiographic evidence of left ventricular dysfunction and pulmonary venous congestion.

\section{Subjects and methods}

Seventeen patients, 15 men and 2 women, were seen within 48 hours of the onset of the major symptom. Informed consent was obtained from each patient and the nature of the study was carefully explained. They were all rested for at least 30 minutes before the study. The average age was 52 years (range 38 to 66 years). Fourteen patients were subsequently shown to have suffered a definite acute myocardial infarction based on W.H.O. criteria Class I (World Health Organization, I97I): 6 of these were anterior, 2 inferior, 4 subendocardial, $I$ had no changes on the electrocardiogram, and the other patient had a left bundle-branch block configuration (Table I). The remaining 3 patients were classified as having suffered a possible acute myocardial infarction (Class 2 by W.H.O. criteria). No patients had cardiogenic shock, severe pulmonary oedema, mitral valve dysfunction, pulmonary disease, or serious arrhythmias. At the time of the study, 9 of these patients had crepitations at the lung bases, I I had an atrial sound, and I I had radiographic evidence of pulmonary venous congestion.
No patients had been given diuretics within the 8 hours preceding the study and only I patient (Case 17) received intranasal oxygen during the study. Standard posteroanterior chest radiographs, tube distance 6 feet, were taken daily with the patient sitting over the side of the bed, and the presence of pulmonary venous congestion was determined using one or more of the following criteria (Logue, Rogers, and Gay, 1963; Tattersfield et al., 1969): I) Blurring of the perihilar region; 2) distension of the upper lobe veins; 3) intraalveolar exudates; 4) Kerley B lines.

The patients were studied at the bedside in the coronary care unit procedure room after full explanation of the procedure and a period of rest. The patient lay with the head on one pillow, and using sterile techniques and local anaesthesia a size $7 \mathrm{~F}$ Swan-Ganz thermodilution catheter (Edwards Laboratories) was inserted into a right antecubital vein and passed 40 to $50 \mathrm{~cm}$ to the superior vena cava where the balloon was inflated. An injection of 2500 units of heparin in $10 \mathrm{ml} 5$ per cent dextrose was then given. If ventricular ectopics were noted, 50 to roo $\mathrm{mg}$ of intravenous lignocaine ( $\mathrm{I} \%$ ) was also given. While the pressure at the catheter tip was monitored the catheter was passed into the pulmonary artery and wedged. Image intensification was not required. Pressure measurements were made using Sanborn differential transducers type $267 \mathrm{~A}$, with the zero level taken at the mid-chest position. The pressure signal was processed using a Hewlett Packard 350-I IOC carrier amplifier and the pressures recorded on a Sample Electronics SE 
3006 ultraviolet recorder using light sensitive paper which provided a high contrast recording within a few minutes under normal light conditions. All pressures were observed on an E.M.I. 4-channel slow scan oscilloscope. From the distal lumen of the Swan-Ganz catheter measurements were made of the pulmonary artery diastolic and pulmonary arterial wedge mean pressures, and a pulmonary artery blood sample was taken for oxygen saturation determination. The blood was collected without any air leak into heparinized glass syringes, placed in ice for transport, and analysed within half an hour using a Beckman Cuvette and Physiological Gas Analyser (Model I60). From the proximal lumen of the Swan-Ganz catheter the right atrial mean pressure was recorded.

Thermodilution cardiac outputs were performed in duplicate by injecting exactly ro $\mathrm{ml}$ cold 5 per cent dextrose (temperature range $0^{\circ} \mathrm{C}$ to $5^{\circ} \mathrm{C}$ ) into the right atrium. The temperature change in the pulmonary artery blood detected by the thermistor at the distal end of the

TABLE 2 Haemodynamic data obtained before and after intravenous and intramuscular injection of frusemide

\begin{tabular}{|c|c|c|c|c|c|c|c|c|c|c|c|}
\hline \multirow{2}{*}{ Case } & & \multicolumn{3}{|c|}{$\begin{array}{l}\text { Pressure } \\
\text { (Swan-Ganz catheter) }\end{array}$} & \multirow{2}{*}{$\begin{array}{l}\text { Arterial } \\
\text { systolic } \\
\text { pressure } \\
(\mathrm{mmHg})\end{array}$} & \multicolumn{2}{|c|}{$\mathrm{O}_{2}$ saturation $\%$} & \multirow{2}{*}{$\begin{array}{l}\text { Cardiac } \\
\text { output } \\
\text { (l./min) }\end{array}$} & \multirow{2}{*}{$\begin{array}{l}\text { Heart } \\
\text { rate } \\
\text { /min }\end{array}$} & \multirow{2}{*}{$\begin{array}{l}\text { Stroke } \\
\text { volume } \\
(\mathrm{ml})\end{array}$} & \multirow{2}{*}{$\begin{array}{l}\text { Peripheral } \\
\text { vascular } \\
\text { resistance } \\
\left(\text { dynes } \sec \mathrm{cm}^{-5}\right)\end{array}$} \\
\hline & & $\begin{array}{l}R A \\
(m m H g)\end{array}$ & $\begin{array}{l}P A D \\
(m m H g)\end{array}$ & $\begin{array}{l}P A W \\
(m m H g)\end{array}$ & & $\begin{array}{l}\text { Pul- } \\
\text { monary } \\
\text { arterial }\end{array}$ & $\begin{array}{l}\text { Syste- } \\
\text { mic } \\
\text { arterial }\end{array}$ & & & & \\
\hline \multicolumn{12}{|c|}{ Intravenous frusemide } \\
\hline & Pre & 3 & I0 & 7 & 135 & 69 & 96 & $7 \cdot 2$ & 65 & III & 1132 \\
\hline \multirow[t]{4}{*}{ I } & $15 \mathrm{~min}$ & 3 & 16 & 7 & 145 & 73 & 94 & $8 \cdot 0$ & 72 & III & 1068 \\
\hline & 30 & 3 & II & 3 & 140 & 72 & 94 & $6 \cdot 0$ & 69 & 87 & 1425 \\
\hline & (60 ", & $-I$ & 9 & 4 & 135 & 70 & 94 & $7 \cdot 0$ & 76 & 93 & 1153 \\
\hline & Pre & 3 & 18 & 16 & 160 & 65 & 90 & $7 \cdot 5$ & 80 & 93 & II93 \\
\hline \multirow[t]{4}{*}{2} & $15 \mathrm{~min}$ & 5 & 19 & II & 155 & 66 & 9I & $5 \cdot 6$ & 78 & 72 & 1659 \\
\hline & 30 " & 6 & 12 & II & 105 & 64 & 93 & $4 \cdot 1$ & $5 I$ & 80 & 1247 \\
\hline & $60 \%$ & 6 & 12 & 7 & IIO & 69 & 92 & $4 \cdot 9$ & 68 & 72 & 1206 \\
\hline & Pre & 7 & II & I0 & 160 & 80 & 97 & $6 \cdot 3$ & 68 & 92 & 1496 \\
\hline \multirow[t]{4}{*}{3} & $\{15 》$ & 5 & 9 & 6 & 145 & 76 & 96 & $5 \cdot 5$ & 62 & 89 & 1598 \\
\hline & $30 \%$ & 4 & 9 & 7 & I55 & 76 & 96 & $5 \cdot 6$ & 64 & 89 & 1655 \\
\hline & & 5 & 9 & 6 & 160 & 78 & 97 & $6 \cdot 0$ & 72 & 83 & 1518 \\
\hline & Pre & I & 8 & I0 & 145 & 69 & 95 & $6 \cdot 8$ & 85 & 79 & 1046 \\
\hline \multirow[t]{4}{*}{4} & $15 \mathrm{~min}$ & 0 & 9 & 4 & 140 & 69 & 94 & 5.9 & 87 & 69 & 1286 \\
\hline & 30 & $-I$ & 8 & 4 & 140 & 72 & 94 & $6 \cdot 0$ & 88 & 68 & 1212 \\
\hline & $60 \%$ & I & 7 & 4 & 135 & 72 & 95 & $6 \cdot 2$ & 88 & 71 & II47 \\
\hline & Pre & 5 & 16 & 8 & 120 & 73 & 93 & $5 \cdot 0$ & 84 & 60 & 1438 \\
\hline \multirow[t]{4}{*}{5} & $\{15 \mathrm{~min}$ & 6 & 14 & 9 & 125 & 73 & 93 & $4 \cdot 9$ & 86 & 57 & 1614 \\
\hline & 30 & 4 & 13 & 7 & 120 & 74 & 92 & $5 \cdot 1$ & 94 & 54 & 1504 \\
\hline & (60 ", & 6 & 17 & I0 & II5 & 65 & 90 & $5 \cdot 3$ & 84 & 61 & 1266 \\
\hline & Pre & I0 & $2 \mathrm{I}$ & 18 & II5 & 73 & 93 & $6 \cdot 6$ & 80 & 81 & 908 \\
\hline \multirow[t]{4}{*}{6} & I5 min & 8 & 18 & 13 & 130 & 75 & 95 & $6 \cdot 3$ & 85 & 74 & 1293 \\
\hline & 30 & 8 & 15 & II & IIS & 76 & 97 & $5 \cdot 3$ & 76 & 69 & 1387 \\
\hline & $60 \%$ & I I & 18 & 14 & 125 & 68 & 94 & $5 \cdot 6$ & 82 & 68 & I34I \\
\hline & Pre & 7 & 28 & 25 & 140 & 78 & 87 & $6 \cdot 0$ & 92 & 65 & 1305 \\
\hline \multirow[t]{4}{*}{7} & I5 $\mathrm{min}$ & 5 & 27 & 18 & 135 & 82 & 97 & $7 \cdot I$ & 94 & 77 & 1125 \\
\hline & 30 & 5 & 33 & 30 & 130 & 83 & 98 & 4.5 & 98 & 46 & 1776 \\
\hline & 60 ") & 4 & 20 & 17 & 125 & 85 & 97 & $5 \cdot 2$ & 98 & 53 & 1552 \\
\hline & Pre & 6 & 13 & 9 & I 20 cuff & $7 \mathrm{I}$ & - & $5 \cdot 1$ & 66 & 76 & - \\
\hline \multirow[t]{4}{*}{8} & $15 \mathrm{~min}$ & 4 & 8 & 7 & I Is cuff & 65 & - & $3 \cdot 6$ & 76 & 48 & - \\
\hline & 30 & 5 & 7 & 6 & I30 cuff & 71 & - & $3 \cdot 8$ & 69 & 55 & - \\
\hline & 60 ", & 3 & I0 & 4 & I25 cuff & 69 & - & $4 \cdot 0$ & 78 & 52 & - \\
\hline & Pre & 20 & 30 & 23 & 135 & 62 & 87 & $6 \cdot 0$ & 106 & 50 & 1357 \\
\hline \multirow[t]{4}{*}{9} & $\{15 \mathrm{~min}$ & 19 & 30 & 22 & I45 & 59 & 86 & $7 \cdot 1$ & IIO & 45 & 1647 \\
\hline & 30 , & 20 & 35 & 28 & 140 & 65 & 84 & $4 \cdot 5$ & 109 & 46 & 1567 \\
\hline & $60 \%$ & I8 & 28 & 20 & 130 & 71 & 86 & $5 \cdot 2$ & IIO & $5 \mathrm{I}$ & I24I \\
\hline & Pre & 9 & 18 & 15 & I20 cuff & $7 I$ & - & $7 \cdot 7$ & 60 & 128 & - \\
\hline \multirow[t]{3}{*}{ Io } & $\{15 \mathrm{~min}$ & IO & 17 & I6 & 130 cuff & 74 & - & $6 \cdot 6$ & 60 & IIO & - \\
\hline & 30 , & IO & 18 & I5 & I 20 cuff & 71 & - & $6 \cdot 8$ & 69 & 99 & 一 \\
\hline & 60, & 5 & 14 & 12 & I I 5 cuff & 74 & - & $6 \cdot 9$ & 70 & 100 & - \\
\hline$\overline{\text { Mean }}$ & Pre & $7 \cdot 1$ & $17 \cdot 3$ & I4. I & 135 & 71 & 94 & $6 \cdot 4$ & 79 & 83.5 & 1234 \\
\hline and & I5 $\mathrm{min}$ & 6.5 & 16.7 & II 3 & 137 & 71 & 93 & $5 \cdot 8$ & $8 \mathrm{r}$ & $75 \cdot 2$ & 1400 \\
\hline & & $>0.2$ & $>0.5$ & $<0.02$ & NS & NS & NS & $>0.10$ & NS & $<0.01$ & $>0.05$ \\
\hline values & $30 "$ & 6.4 & I6.I & $12 \cdot 2$ & 130 & 72 & 94 & $5 \cdot 2$ & 79 & $69 \cdot 3$ & 1471 \\
\hline & & $>0.2$ & $>0.3$ & $>70.01$ & NS & NS & NS & $<0.005$ & NS & $<0.001$ & $<0.005$ \\
\hline & 60 ", & $\begin{array}{r}5 \cdot 7 \\
>0 \cdot 1\end{array}$ & $\begin{array}{c}14.4 \\
<0.001\end{array}$ & $\begin{array}{l}\text { IO.I } \\
<0.005\end{array}$ & $\begin{array}{l}\text { I28 } \\
\text { NS }\end{array}$ & $\begin{array}{l}72 \\
\text { NS }\end{array}$ & $\begin{array}{l}93 \\
\text { NS }\end{array}$ & $\begin{array}{c}5.7 \\
<0.05\end{array}$ & $\begin{array}{l}83 \\
\text { NS }\end{array}$ & $\begin{array}{l}70.4 \\
<0.005\end{array}$ & $\begin{array}{l}1303 \\
>0.1\end{array}$ \\
\hline
\end{tabular}


TABLE 2 (Cont'd)

\begin{tabular}{|c|c|c|c|c|c|c|c|c|c|c|c|}
\hline \multirow{2}{*}{ Case } & & \multicolumn{3}{|c|}{$\begin{array}{l}\text { Pressure } \\
\text { (Swan-Ganz catheter) }\end{array}$} & \multirow{2}{*}{$\begin{array}{l}\text { Arterial } \\
\text { systolic } \\
\text { pressure } \\
(\mathrm{mmHg})\end{array}$} & \multicolumn{2}{|c|}{$\mathrm{O}_{2}$ saturation $\%$} & \multirow{2}{*}{$\begin{array}{l}\text { Cardiac } \\
\text { output } \\
(\text { l. } / \text { min })\end{array}$} & \multirow{2}{*}{$\begin{array}{l}\text { Heart } \\
\text { rate } \\
\text { Imin }\end{array}$} & \multirow{2}{*}{$\begin{array}{l}\text { Stroke } \\
\text { volume } \\
(m l)\end{array}$} & \multirow{2}{*}{$\begin{array}{l}\text { Peripheral } \\
\text { vascular } \\
\text { resistance } \\
\left(\text { dynes sec } \mathrm{cm}^{-5} \text { ) }\right.\end{array}$} \\
\hline & & $\begin{array}{l}R A \\
(m m H g)\end{array}$ & $\begin{array}{l}P A D \\
(m m H g)\end{array}$ & $\begin{array}{l}P A W \\
(m m H g)\end{array}$ & & $\begin{array}{l}\text { Pul- } \\
\text { monary } \\
\text { arterial }\end{array}$ & $\begin{array}{l}\text { Syste- } \\
\text { mic } \\
\text { arterial }\end{array}$ & & & & \\
\hline \multicolumn{12}{|c|}{ Intramuscular frusemide } \\
\hline & Pre & 7 & 20 & 19 & 170 & 75 & 96 & $5 \cdot 3$ & 84 & 63 & 1704 \\
\hline \multirow[t]{4}{*}{ II } & I5 $\mathrm{min}$ & 5 & 17 & 15 & 180 & 71 & 96 & $5 \cdot 1$ & 84 & $6 I$ & 1959 \\
\hline & $30 \%$ & 6 & 14 & Io & 180 & 75 & 96 & $4 \cdot 6$ & 74 & 62 & 2154 \\
\hline & $60 \%$ & 5 & 13 & 8 & 185 & 70 & 97 & $4 \cdot 0$ & 89 & 45 & 2697 \\
\hline & Pre & 8 & 14 & II & 130 & 81 & 96 & $6 \cdot 3$ & 76 & 84 & 1231 \\
\hline \multirow[t]{4}{*}{12} & I5 $\mathrm{min}$ & 6 & 13 & I0 & 130 & 76 & 93 & $6 \cdot 2$ & 85 & 73 & 1237 \\
\hline & 30 & 5 & 12 & 9 & 140 & 75 & 93 & $5 \cdot 2$ & 76 & 69 & 1614 \\
\hline & $60 \%$ & 4 & 12 & 7 & 145 & 74 & 93 & $5 \cdot 4$ & 80 & 68 & I569 \\
\hline & Pre & II & 13 & 14 & 110 & 65 & 97 & $4 \cdot I$ & $5 I$ & 80 & II 50 \\
\hline \multirow[t]{4}{*}{13} & $15 \mathrm{~min}$ & I I & 13 & 13 & 125 & 67 & 98 & $4 \cdot 0$ & 50 & 83 & I478 \\
\hline & $30 "$ & IO & 13 & 12 & 120 & 67 & 98 & $4 \cdot 0$ & 48 & 83 & I499 \\
\hline & $60 \%$ & I0 & 12 & II & 125 & 67 & 98 & $3 \cdot 8$ & 48 & 79 & I 577 \\
\hline & Pre & 13 & $3 I$ & 27 & 110 & 53 & 95 & $5 \cdot 1$ & 136 & 37 & I 128 \\
\hline \multirow[t]{4}{*}{14} & $15 \mathrm{~min}$ & 16 & 34 & 27 & 115 & 48 & 94 & 6.4 & 134 & 47 & 924 \\
\hline & 30 & 13 & 34 & 26 & I10 & 61 & 90 & 4.9 & 133 & 37 & 1256 \\
\hline & 60, & 13 & 30 & 22 & II5 & 55 & 95 & 5.9 & 133 & 45 & 1043 \\
\hline & Pre & 7 & 13 & 7 & - & 69 & - & $5 \cdot 2$ & 82 & 64 & - \\
\hline \multirow[t]{4}{*}{15} & $\{15 \mathrm{~min}$ & 7 & 14 & 10 & - & 64 & - & $4 \cdot 8$ & $8 I$ & 60 & - \\
\hline & 30 & 8 & II & 8 & - & 66 & - & $4 \cdot 3$ & 82 & 52 & - \\
\hline & $60 \%$ & 5 & 13 & 8 & - & 68 & - & $4 \cdot 2$ & 89 & 46 & - \\
\hline & Pre & 7 & 25 & 22 & I 10 & 48 & 79 & $4 \cdot 3$ & 104 & 40 & 1450 \\
\hline \multirow[t]{4}{*}{ I6 } & $\{15 \mathrm{~min}$ & 7 & 24 & 20 & 105 & 43 & 77 & $3 \cdot 8$ & 105 & 36 & 1640 \\
\hline & $30 "$ & 6 & 23 & 20 & IIO & 50 & 78 & 3.8 & 107 & 36 & 1767 \\
\hline & $60 \%$ & 5 & 21 & 18 & 115 & 40 & 84 & $3 \cdot 6$ & IIO & 33 & 1887 \\
\hline & Pre & 4 & I4 & 6 & 150 & 78 & 99 & $4 \cdot 2$ & 96 & 44 & 2017 \\
\hline \multirow[t]{3}{*}{ I7 } & $15 \mathrm{~min}$ & 3 & II & 6 & 155 & 78 & 99 & 3.9 & 98 & 40 & 2295 \\
\hline & , & 4 & II & 5 & 150 & 75 & 99 & 3.9 & 102 & 38 & 2275 \\
\hline & $60 \%$ & 4 & I0 & 5 & 145 & 72 & 98 & 3.5 & 105 & 34 & 2420 \\
\hline \multirow{5}{*}{$\begin{array}{l}\text { Mean } \\
\text { and } \\
P \\
\text { values }\end{array}$} & Pre & $8 \cdot I$ & 18.6 & $15 \cdot 1$ & 130 & 67 & 94 & 4.9 & 90 & $58 \cdot 8$ & I447 \\
\hline & $15 \%$ & $\begin{array}{l}7 \cdot 9 \\
I\end{array}$ & $\begin{array}{l}18.0 \\
<0.06\end{array}$ & $\begin{array}{r}14.4 \\
<0.5\end{array}$ & $\begin{array}{l}135 \\
<0.4\end{array}$ & $\begin{array}{l}64 \\
\text { NS }\end{array}$ & $\begin{array}{l}93 \\
\text { NS }\end{array}$ & $\begin{array}{r}4.9 \\
<0.4\end{array}$ & $\begin{array}{l}91 \\
\text { NS }\end{array}$ & $\begin{array}{l}57.1 \\
<0.5\end{array}$ & $\begin{array}{l}1589 \\
>0.10\end{array}$ \\
\hline & $30 \%$ & $\begin{array}{l}7.5 \\
<0.02\end{array}$ & $\begin{array}{l}16.9 \\
<0.2\end{array}$ & $\begin{array}{r}12.8 \\
<0.2\end{array}$ & $\begin{array}{l}155 \\
<0.8\end{array}$ & $\begin{array}{l}67 \\
\text { NS }\end{array}$ & 92 & $\begin{array}{r}4.4 \\
<0.8\end{array}$ & $\begin{array}{l}89 \\
\text { NS }\end{array}$ & $\begin{array}{r}53.8 \\
<0.7\end{array}$ & $\begin{array}{l}1761 \\
<0.001\end{array}$ \\
\hline & & 6.6 & 15.9 & II.2 & 140 & 64 & 94 & $4 \cdot 3$ & 93 & 50.0 & 1866 \\
\hline & $60 \%$ & $<0.1$ & $<0.09$ & $<0.2$ & $<0.1$ & NS & NS & $<0.1$ & NS & $<0.2$ & $<0.05$ \\
\hline
\end{tabular}

Note: The mean and ' $P$ ' values are given at the end of each study.

RA, right atrial mean; PAD, pulmonary artery diastolic; PAW, pulmonary arterial wedge mean.

catheter resulted in an off-balance output from a Wheatstone bridge which was amplified and recorded at $4 \mathrm{~mm} / \mathrm{sec}$ on a Kipp and Zonen BD 3 micrograph potentiometric recorder calibrated before each study. The thermodilution catheter had previously been calibrated over a temperature range $33^{\circ}$ to $39^{\circ} \mathrm{C}$, using a Marconi Universal Bridge T.F. 2700. The area under the temperature time curve obtained on the Kipp and Zonen recorder was determined by planimetry and the cardiac output calculated from the following equation.

$$
\mathrm{CO}=\frac{0.535 \times\left(\mathrm{T}_{\mathrm{B}}-\mathrm{T}_{\mathrm{I}}\right) \times \mathrm{T}_{\mathrm{A}}}{5 \mathrm{~A}_{\mathrm{p}}}
$$

where,

CO is the cardiac output in litres/minute; $T_{B}$ is the temperature of the blood $\left({ }^{\circ} \mathrm{C}\right) ; T_{I}$ is the temperature of the injectate $\left({ }^{\circ} \mathrm{C}\right) ; T_{A}$ is the area of calibration; and $A_{p}$ is the area under the temperature time curve.

This working formula was derived from the equation recommended by the manufacturers of the catheter (Ganz and Swan, 1972).

Arterial pressure recordings were made in 14 patients using a fine $4 \mathrm{~F}$ portex cannula passed by the Seldinger technique into the femoral or brachial artery. In I4 patients arterial blood samples were taken and the oxygen saturation determined. In 3 patients arterial pressures were measured by a cuff sphygmomanometer.

After the recording of the baseline measurements, $40 \mathrm{mg}$ frusemide was given by intravenous injection over 5 minutes in 10 patients and by the intramuscular route in 7 patients. The haemodynamic measurements were repeated at 15,30 , and 60 minutes after the injection. Before the study the patient was requested to empty 
his bladder and this was repeated at the end of one hour or earlier if necessary. The volume of urine passed over one hour was measured.

Stroke volume $(\mathrm{ml})$ was obtained from the following formula:

\section{$\frac{\text { Cardiac output } \mathrm{ml} / \mathrm{min}}{\text { Heart rate } / \mathrm{min}}$}

Peripheral vascular resistance (dynes $\sec \mathrm{cm}^{-5}$ ) was obtained from the following formula:

$$
1332 \times 60 \times \frac{\begin{array}{l}
\text { mean arterial } \\
\text { pressure }(\mathrm{mmHg})
\end{array}-\begin{array}{l}
\text { mean right atrial } \\
\text { pressure }(\mathrm{mmHg})
\end{array}}{\text { Cardiac output }(\mathrm{ml} / \mathrm{min})}
$$

There were no complications associated with the study apart from sinus bradycardia in one patient which required treatment with atropine sulphate.

\section{Results}

The clinical features of the patients are listed in Table I, and the haemodynamic data in Table 2.

\section{Urine output}

There was an excellent urinary response to both the intravenous and intramuscular injections of frusemide, the mean volumes being $770 \mathrm{ml}$ over the 60 minutes for the intravenous study (range 400 to $1300 \mathrm{ml}$ ) and $910 \mathrm{ml}$ over the 60 minutes for the intramuscular study (range 300 to $1680 \mathrm{ml}$ ). The mean volume for all cases was $830 \mathrm{ml}$.

There was no relation between the initial haemodynamic data, the haemodynamic response to frusemide, and the volume of urine passed.

\section{I) Intravenous frusemide (10 patients)}

Right atrial mean pressure There was a gradual fall in the mean right atrial pressure over the 60 minutes after the intravenous injection of frusemide (7. I mmHg falling to $5.7 \mathrm{mmHg}$ ). However, this fall was not statistically significant $(P>0 \cdot I)$.

Pulmonary artery diastolic pressure (Fig. I) A statistically significant fall in the mean pulmonary artery diastolic pressure occurred after 60 minutes following the injection $(17.3 \mathrm{mmHg}$ falling to 14.4 $\mathrm{mmHg})(\mathrm{P}<0.00 \mathrm{I})$. However, in the 2 patients with the highest initial pulmonary artery diastolic pressure, this pressure rose at 30 minutes, and coincided with the complaint of a painful distended bladder. After micturition the pulmonary artery diastolic pressures fell.

Pulmonary arterial wedge mean pressure (Fig. 2) There was a statistically significant fall in the mean pulmonary arterial wedge pressure at 60 minutes after the injection ( $14.1 \mathrm{mmHg}$ falling to $10.1 \mathrm{mmHg})(\mathrm{P}<0.005)$. Though the fall was significant at 15 minutes, the mean pulmonary arterial wedge pressure rose again at 30 minutes. This was caused by a sharp rise in the pulmonary arterial wedge pressures of the same 2 patients who showed a rise in the pulmonary artery diastolic pressures. These patients had the highest pulmonary arterial wedge pressures and after micturition the pressures fell.

Arterial systolic pressure, blood gases, and heart rate There was little alteration in any of these measurements over the 60 minutes after the injection.

Cardiac output (Fig. 3) There was a fall in the mean cardiac output after the injection, this fall being most significant at 30 minutes $(6.4 \mathrm{l} . / \mathrm{min}$, falling to $5.21 . / \mathrm{min})(\mathrm{P}<0.005)$. At 60 minutes the fall was still significant but the mean cardiac output had risen again to 5.71 ./min $(P<0.05)$.

Stroke volume (Fig. 4) There was a significant fall in the mean stroke volume. This was maximum at 30 minutes $(83.5 \mathrm{ml}$ falling to $69.3 \mathrm{ml})(P<$ 0.001 ), but the fall was also significant at $15 \mathrm{~min}$ utes $(\mathbf{P}<0.01)$ and 60 minutes $(\mathbf{P}<0.005)$.

Peripheral vascular resistance There was a statistically significant rise in the peripheral vascular resistance 30 minutes after the injection (I234 dynes sec cm-5 rising to $147 \mathrm{I}$ dynes $\sec \mathrm{cm}^{-5}$ ) $(\mathrm{P}<0.005)$.

Ventricular function (Fig. 5) The cardiac output, before injection and 60 minutes later, was graphed against the pulmonary arterial wedge pressures at those times. In 9 cases there was a fall in both the cardiac output and the pulmonary arterial wedge pressure. In the other case a rise in the cardiac output occurred from the preinjection value of $5.31 . / \mathrm{min}$ to $5.61 . / \mathrm{min}$ at 60 minutes.

\section{2) Intramuscular frusemide (7 patients)}

Right atrial mean pressure There was a gradual fall in the mean right atrial pressure over the 60 minutes following the intramuscular injection of frusemide $(8 . \mathrm{I} \mathrm{mmHg}$ falling to $6.6 \mathrm{mmHg})$. However, this fall was not statistically significant $(\mathbf{P}>0 \cdot \mathbf{I})$.

Pulmonary artery diastolic pressure (Fig. 6) A statistically significant fall in the mean pulmonary artery diastolic pressure occurred after 60 minutes following the injection $(18.6 \mathrm{mmHg}$ falling to $15.9 \mathrm{mmHg})(\mathrm{P}<0.02)$. 


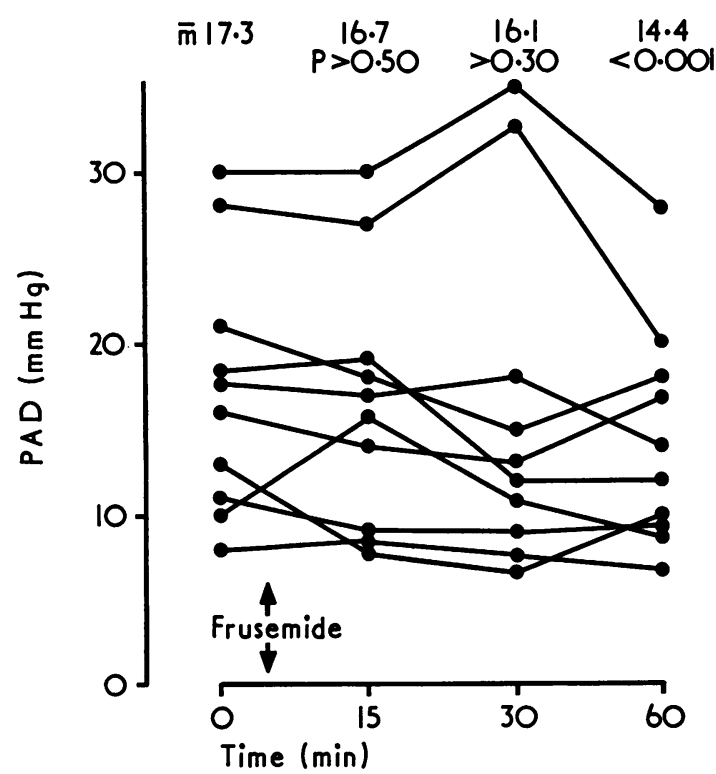

FIG. I Effect of an intravenous injection of frusemide on the pulmonary artery diastolic pressure. There was a significant fall at 60 minutes $(P<0.001)$.

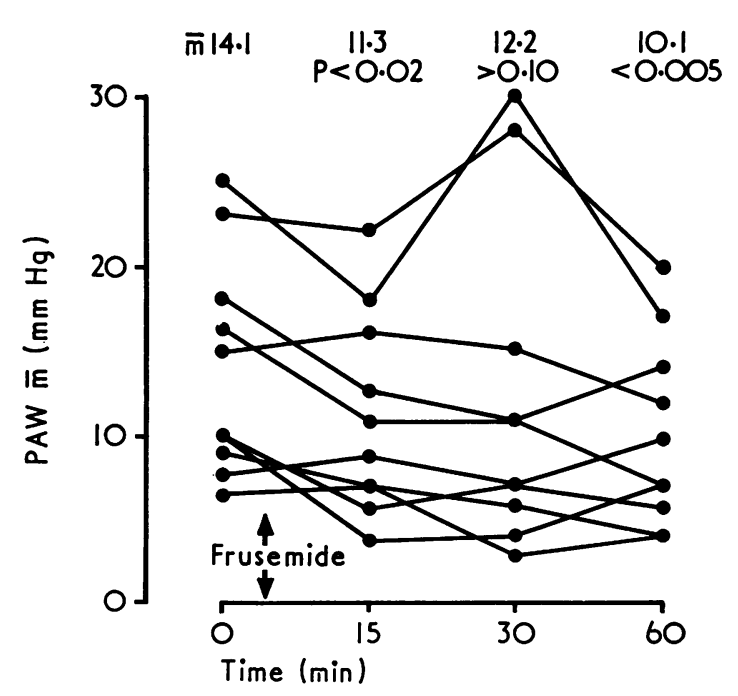

FIG. 2 Effect of an intravenous injection of frusemide on the pulmonary arterial wedge mean pressure. There was a significant fall at 15 minutes $(P<0.02)$ and again at 60 minutes $(P<0.005)$.

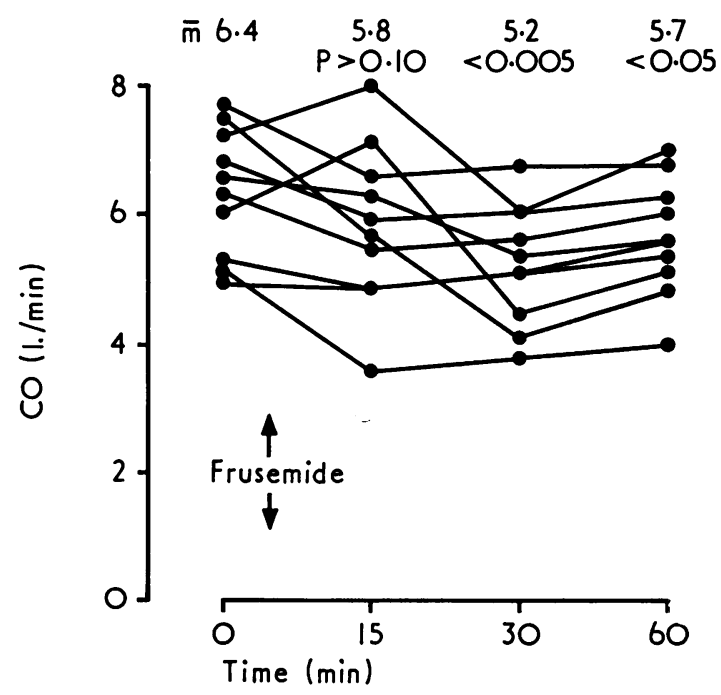

FIG. 3 Effect of an intravenous injection of frusemide on the cardiac output. There was a significant fall at 30 minutes $(P>0.005)$ and again at $60 \mathrm{~min}$ utes $(P<0.05)$.

FIG. 4 Effect of an intravenous injection of frusemide on the stroke volume. There was a significant fall at 15 minutes $(P<0.01)$, 30 minutes $(P<0.001)$, and 60 minutes $(P<0.005)$. 
Pulmonary arterial wedge mean pressure A fall in the mean pulmonary arterial wedge pressure occurred in the 60 minutes after the injection ( $15.1 \mathrm{mmHg}$ falling to $11 \cdot 2 \mathrm{mmHg}$ ). However this fall was not statistically significant $(P<0 \cdot 2)$.

Arterial systolic pressure, blood gases, and heart rate There was little alteration in any of these measurements over the 60 minutes after the injection.

Cardiac output (Fig. 7) There was a fall in the cardiac output after the injection $(4.91 . / \mathrm{min}$ falling to $4.31 . / \mathrm{min}$ at 60 minutes), but this fall was not statistically significant $(P<0 \cdot I)$.

Stroke volume There was a fall in the stroke volume after the injection $(58.8 \mathrm{ml}$ falling to $50.0 \mathrm{ml}$ at 60 minutes), but this fall was not statistically significant $(\mathbf{P}<0 \cdot 2)$.

Peripheral vascular resistance There was a statistically significant rise in the peripheral vascular resistance at 30 minutes (I447 dynes $\mathrm{sec} \mathrm{cm}^{-5}$ rising to $176 \mathrm{I}$ dynes $\left.\mathrm{sec} \mathrm{cm}^{-5}\right)(\mathrm{P}<0.00 \mathrm{I})$, and 60 minutes $\left(1866\right.$ dynes $\left.\mathrm{sec} \mathrm{cm}^{-5}\right)(\mathrm{P}<0.05)$ after the injection.

Ventricular function (Fig. 8) The cardiac output, both before the injection and 60 minutes later, was graphed against the pulmonary arterial wedge pressure at those times. In 5 cases there was a fall in both the cardiac output and pulmonary arterial wedge pressure. In one case the cardiac output rose (this patient had the highest pulmonary arterial wedge present) and in another case the pulmonary arterial wedge pressure rose $\mathrm{I} \mathrm{mmHg} 60$ minutes after the injection.

\section{Discussion}

Parenteral frusemide will result in a prompt diuresis and significant haemodynamic changes apparent between 30 and 60 minutes in patients with suspected acute myocardial infarction. With the intravenous injection, there were significant falls in the cardiac output, stroke volume, pulmonary artery diastolic, and pulmonary arterial wedge pressures, together with a significant rise in the peripheral vascular resistance. Similar haemodynamic trends occurred with the intramuscular injection of frusemide; however, the only significant alterations were the fall in the pulmonary artery diastolic pressure at 60 minutes and the rise in peripheral vascular resistance at 30 and 60 minutes.

After an intravenous injection of frusemide in patients with acute myocardial infarction, other workers have reported a fall in the pulmonary artery pressure (Sjogren, 1970; Tattersfield and McNicol, 1970; Davidson et al., 197I), left ventricular end-diastolic pressure (Amsterdam et al., 1972), and pulmonary arterial wedge pressure (Kiely et al., 1972). This fall in the left ventricular filling pressure measured either directly or indirectly via the pulmonary artery diastolic or pulmonary arterial wedge pressures (Sapru, Taylor, and Donald, 1968; Forsberg, 1971 ; Balcon, Bennett, and Sowton, 1972), together with a fall in the stroke volume, suggests intravascular fluid depletion, resultant upon the diuresis.

Although only statistically significant after the intravenous injection, the cardiac output was shown to fall after parenteral frusemide. The blood pressure however was maintained, because of a concomitant rise in peripheral vascular resistance, presumably caused by the activity of baroceptor reflexes (Loeb et al., 1969). Sjogren (1970) showed a similar decrease in the cardiac output and stroke volume together with a rise in the peripheral vascular resistance in some of his patients after an intravenous injection of frusemide, but the mean values overall did not show significant change. Other authors do, however, show significant falls in the cardiac output and stroke volume (Tattersfield and McNicol, I970; Davidson et al., 1971).

After the intravenous administration of frusemide, the failure of the right atrial pressure to show a significant fall, despite the fall in pulmonary arterial wedge pressure, further emphasizes the failure of this pressure to reflect changes in the left ventricular filling pressure. The right atrial pressure, being dependent on the peripheral venous tone and compliance of the right ventricle, correlates poorly as a static pressure with the pulmonary artery diastolic, pulmonary arterial wedge, and left ventricular end-diastolic pressures (Rapaport and Scheinman, 1969; Ramo et al., I970; Gunnar and Loeb, 1972; Russell et al., 1972; Mond, Hunt, and Sloman, 1973a). Despite this finding, one group has shown a significant reduction in the right atrial pressure after an intravenous injection of $40 \mathrm{mg}$ frusemide in patients with pulmonary congestion after acute myocardial infarction (Coltart and Hamer, I97I).

The pulmonary artery and systemic arterial blood oxygen saturations did not alter significantly in the 60 minutes after the intravenous injection of frusemide. It has been emphasized by other workers that the hypoxaemia accompanying left ventricular failure fails to improve rapidly after frusemide, and the much slower clearance of interstitial oedema, as contrasted with the rapid reduction in pulmonary blood 


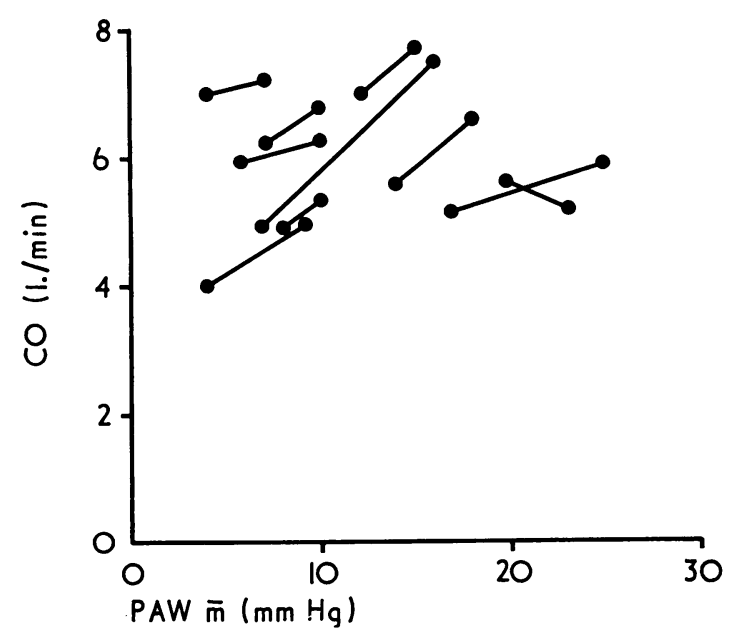

FIG. 5 The cardiac output is plotted against the pulmonary arterial wedge mean pressure, both before and 60 minutes after an intravenous injection of frusemide. In all cases there was a fall in the pulmonary arterial wedge pressure, and in 9 cases there was a concomitant fall in the cardiac output suggesting that the heart functioned along the ascending limb of the ventricular function curve. In one patient with a high initial pulmonary arterial wedge pressure the cardiac output rose after frusemide.

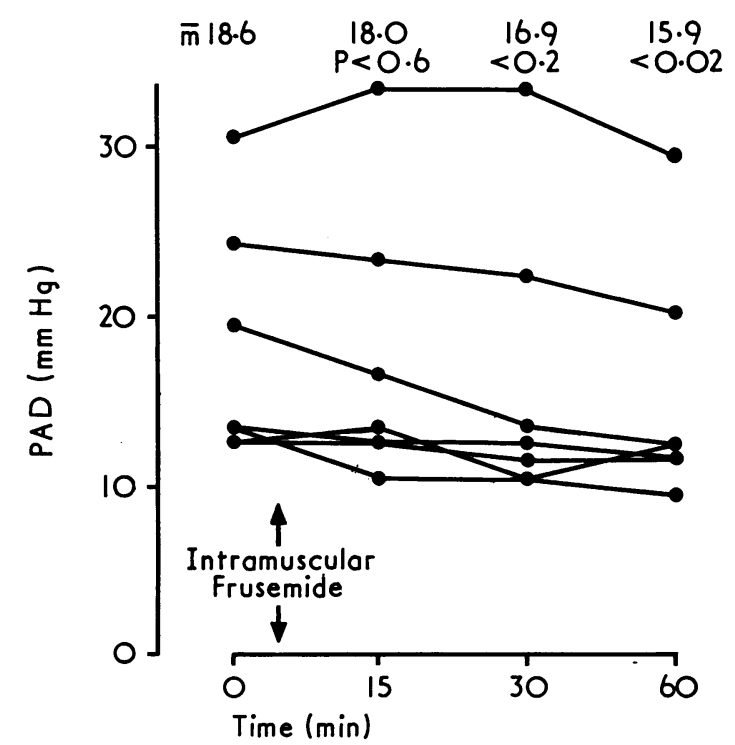

FIG. 6 Effect of an intramuscular injection of frusemide on the pulmonary artery diastolic pressure. There was a significant fall at 60 minutes $(P<0.02)$.

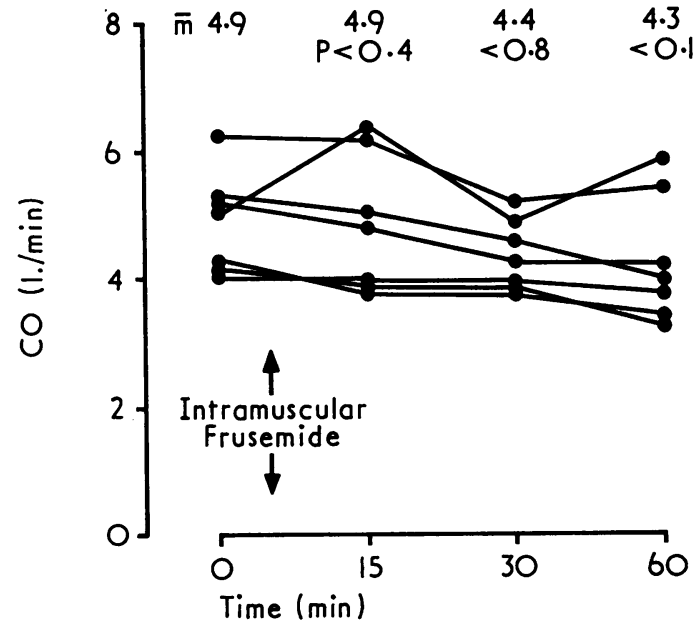

FIG. 7 Effect of an intramuscular injection of frusemide on the cardiac output. There was a gradual fall in the output over 60 minutes but this was not statistically significant $(P<0 \cdot I)$.

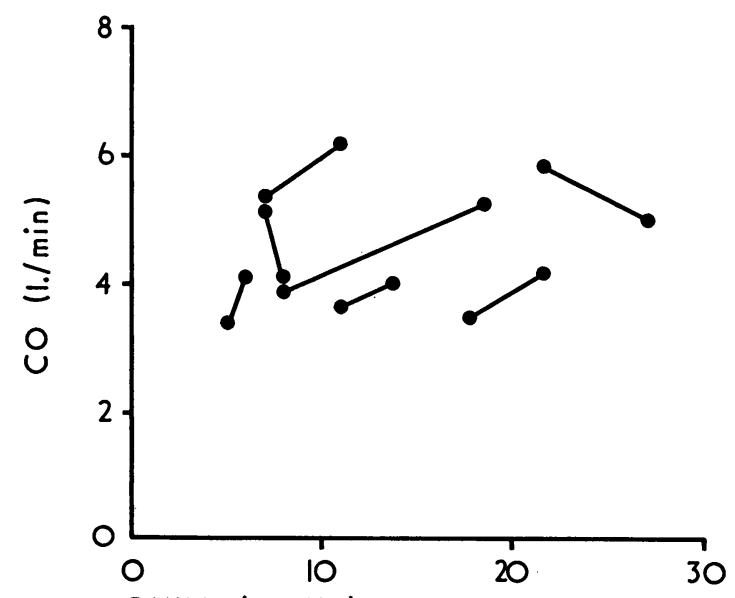

PAW $\bar{m}(\mathrm{~mm} \mathrm{Hg})$

Intramuscular Frusemide

FIG. 8 The cardiac output is plotted against the pulmonary arterial wedge mean pressure both before and 60 minutes after an intramuscular injection of frusemide. In 5 cases there was a fall in both the pulmonary arterial wedge pressure and cardiac output. In I case the cardiac output rose and in another case the pulmonary wedge pressure rose $1 \mathrm{mmHg}, 60$ minutes after the frusemide. 
volume, probably explains the slow improvement in gas exchange (Iff and Flenley, I97I).

By graphing the cardiac output against the filling pressure of the left ventricle (the pulmonary arterial wedge pressure), ventricular function curves were constructed for both the intravenous and the intramuscular frusemide studies. They showed that cardiac function after a diuresis followed the ascending limb of the function curve. These results are in agreement with those of Stampfer et al. (1968) and Lal et al. (1969).

Kiely et al. (1972) have shown that in patients after acute myocardial infarction, a good diuretic response to frusemide indicated a good prognosis, whereas a failure indicated a group with poor renal perfusion and a high mortality. None of the patients in our series had severe pulmonary oedema and all had an excellent urinary response to frusemide whether it was given by the intravenous or intramuscular route.

There was very little difference between the response to the intravenous and intramuscular injections of frusemide in this study. Though statistically the intravenous route had a more significant haemodynamic response, this was not striking when the mean values were compared. Both groups had similar haemodynamic data at the beginning of the study. The fall in cardiac output after parenteral frusemide was more obvious in the intravenous study and had reached its lowest level at $30 \mathrm{~min}$ utes. After the intramuscular injection of frusemide the drop was more gradual, suggesting that this route of administration might be safer in patients with left ventricular failure after acute myocardial infarction.

Serious complications of potent diuretics, namely excessive plasma loss, hypotension, and shock, as suggested by Wolk et al. (1972), were not seen in this study, nor in other reported series where frusemide in intravenous doses of 40 to $80 \mathrm{mg}$ was given to patients after acute myocardial infarction (Sjogren, 1970; Stock, 1970; Tattersfield and McNicol, 1970; Coltart and Hamer, 1971; Davidson et al., 1971; Amsterdam et al., 1972; Kiely et al., 1972). However, in a previously reported case, overenthusiastic diuretic therapy combined with inadvertent fluid restriction resulted in a very low left ventricular filling pressure (Mond et al., 1973a).

Because of the rapid and potent action of parenteral frusemide (Sjogren, 1970; Davidson et al., 1971; Tattersfield, 1972), it has been recommended in the treatment of left ventricular failure after acute myocardial infarction (Stock, 1970). The value of potent diuretic treatment in patients with mild left ventricular failure after an acute myocardial infarction is, however, debatable. In this study the fall in the left ventricular filling pressure reduced the cardiac output, but the blood pressure remained unaltered because of an increased peripheral vascular resistance. This situation suggests a reduction in the cardiac work load (Stampfer et al., 1968; Lal et al., 1969; Sjogren, 1970), and by this means the reduction of the left ventricular filling pressure may be beneficial. However, we know of no reports to suggest that early and vigorous treatment of left ventricular dysfunction with diuretics aids the survival of such patients.

After acute myocardial infarction there is a reduction in the compliance of the left ventricle, even in the early phase (Diamond and Forrester, 1972), and consequently a raised left ventricular filling pressure may be beneficial in order to distend the stiffened ventricle. Thus, a raised filling pressure may be a compensating mechanism advantageous to the failing left ventricle. We, therefore, emphasize the need for caution in the use of vigorous intravenous diuretic therapy in patients with lesser degrees of left ventricular failure (McDonald and McDonald, 1972).

Russell et al. (1972) have recommended that the left ventricular end-diastolic pressure after acute myocardial infarction should be regulated between 18 and $22 \mathrm{mmHg}$ to obtain the maximum cardiac output. They further suggest that in patients whose initial filling pressures are above $25 \mathrm{mmHg}$ reduction of this pressure is certainly indicated by the use of diuretics. If one accepts these criteria only 4 of our patients should have been given frusemide. This problem is further complicated by the unreliability of the clinical signs of left ventricular dysfunction after acute myocardial infarction (Sjogren, 1970; Lassers et al., 1970; McHugh et al., 1970; Rutherford et al., 1971; Mond et al., 1973b).

In summary, parenteral frusemide should not be given routinely to patients after acute myocardial infarction, but should be reserved for those cases with definite clinical, radiographic, or haemodynamic evidence of left ventricular failure. Because of the gradual fall in cardiac output, the intramuscular route of administration is preferred. In subjects with left ventricular failure, immediate administration is indicated but in any case where there is clinical or radiographic doubt, the left ventricular filling pressure, as reflected through the pulmonary artery diastolic and pulmonary arterial wedge pressure, should be measured before therapy is decided.

\section{References}

Amsterdam, E. A., Huffaker, H. K., Demaria, A., Vismara, L. A., Choquet, Y., Massumi, R. A., Zelis, R., and Mason, D. T. (1972). Hemodynamic effects of digitalis in acute myocardial infarction and comparison with furosemide (abstract). Circulation, 46, Suppl. II, II3. 
Balcon, R., Bennett, E. D., and Sowton, G. E. (1972). Comparison of pulmonary artery diastolic and left ventricular end diastolic pressures in patients with ischaemic heart disease. Cardiovascular Research, 6, 172.

Coltart, D. J., and Hamer, J. (1971). Response to rapid infusion or diuresis in acute cardiac infarction. British Heart fournal, 33, 72.

Davidson, R. M., Goldman, J., Jr., Whalen, R. E., and Wallace, A. G. (197I). Hemodynamic effects of furosemide in acute myocardial infarction (abstract). Circulation, 44, Suppl. II, 156.

Diamond, G., and Forrester, J. S. (1972). Effect of coronary artery disease and acute myocardial infarction on left ventricular compliance in man. Circulation, 45, II.

Dowling, J. T., Sloman, G., and Urquhart, C. (1971). Systolic time interval fluctuations produced by acute myocardial infarction. British Heart fournal, 33, 765 .

Fluck, D. C., Valentine, P. A., Treister, B., Higgs, B., Reid, D. N., Steiner, R. E., and Mounsey, J. P. D. (1967). Right heart pressures in acute myocardial infarction. British Heart fournal, 29, 748.

Forsberg, S. A. (197I). Relations between pressure in pulmonary artery, left atrium, and left ventricle with special reference to events at end diastole. British Heart fournal, 33, 494 .

Fowler, N. O. (1968). Physical signs in acute myocardial infarction and its complications. Progress in Cardiovascular Diseases, 10, 287.

Ganz, W., and Swan, H. J. C. (1972). Measurement of blood flow by thermodilution. American fournal of Cardiology, 29, $24 \mathrm{I}$.

Gunnar, R. M., and Loeb, H. S. (1972). Use of drugs in cardiogenic shock due to acute myocardial infarction. Circulation, 45, I I II.

Iff, H. W., and Flenley, D. C. (197I). Blood-gas exchange after frusemide in acute pulmonary oedema. Lancet, 1, 616.

Karliner, J. S., and Ross, J., Jr. (1971). Left ventricular performance after acute myocardial infarction. Progress in Cardiovascular Diseases, 13, 374.

Kiely, J., Kelly, D., Taylor, D., and Pitt, B. (1972). Role of furosemide in the therapy of left ventricular failure due to acute myocardial infarction (abstract). Circulation, 46, Suppl. II, 175 .

Lal, S., Murtagh, J. G., Pollock, A. M., Fletcher, E., and Binnion, P. F. (1969). Acute haemodynamic effects of frusemide in patients with normal and raised left atrial pressures. British Heart fournal, 3I, 7 I I.

Lassers, B. W., George, M., Anderton, J. L., Higgins, M. R., and Philp, T. (1970). Left ventricular failure in acute myocardial infarction. American fournal of Cardiology, 25, 5 II.

Loeb, H. S., Pietras, R. J., Tobin, J. R., and Gunnar, R. M. (1969). Hypovolemia in shock due to acute myocardial infarction. Circulation, 40, 653.

Logue, R. B., Rogers, J. V., Jr., and Gay, B. B., Jr. (1963). Subtle roentgenographic signs of left heart failure. American Heart fournal, 65, 464.

McDonald, L., and McDonald, A. (1972). In Textbook of Coronary Care, p. 547. Ed. by E. Meltzer and A. J. Dunning. Excerpta Medica, Amsterdam.
McHugh, T., Adler, L., Zion, D., Swan, H. J. C., and Forrester, J. S. (I970). Simultaneous hemodynamic, radiologic and physiologic evaluation of left ventricular failure in acute myocardial infarction (abstract). Chest, 58, 285.

Mond, H., Hunt, D., and Sloman, G. (1973a). Haemodynamic monitoring in the coronary care unit using the SwanGanz right heart catheter. British Heart fournal, 35, 635 .

Mond, H., Hunt, D., and Sloman, G. (1973b). A reassessment of the signs of left ventricular failure in acute myocardial infarction, using haemodynamic data. European fournal of Cardiology. In the press.

Rackley, C. E., and Russell, R. O. (1972). Left ventricular function in acute myocardial infarction and its clinical significance. Circulation, 45, $23 \mathrm{I}$.

Ramo, B. W., Myers, N., Wallace, A. G., Starmer, F., Clark, D. O., and Whalen, R. E. (1970). Hemodynamic findings in 123 patients with acute myocardial infarction on admission. Circulation, 42, 567.

Rapaport, E., and Scheinman, M. (1969). Rationale and limitations of hemodynamic measurements in patients with acute myocardial infarction. Modern Concepts of Cardiovascular Disease, 38, 55.

Russell, R. O., Jr., Hunt, D., Potanin, C., and Rackley, C. E. (1972). Hemodynamic monitoring in a coronary intensive care unit. Archives of Internal Medicine, 130, 370.

Rutherford, B. D., McCann, W. D., and O'Donovan, T. P. B. (I97I). The value of monitoring pulmonary artery pressure for early detection of left ventricular failure following myocardial infarction. Circulation, 43, 655 .

Sapru, R. P., Taylor, S. H., and Donald, K. W. (1968). Comparison of the pulmonary wedge pressure with the left ventricular end-diastolic pressure in man. Clinical Science, 34, 125.

Sjogren, A. (1970). Left heart failure in acute myocardial infarction. Acta Medica Scandinavica, Suppl. 5 IO.

Stampfer, M., Epstein, S. E., Beiser, G. D., and Braunwald, E. (1968). Hemodynamic effects of diuresis at rest and during intense upright exercise in patients with impaired cardiac function. Circulation, 37, 900.

Stock, E. (1970). Frusemide after recent myocardial infarction. Medical fournal of Australia, I, 480.

Tattersfield, A. E. (1972). Effects of frusemide on gas exchange in left ventricular failure (abstract). Thorax, 27, 260.

Tattersfield, A. E., and McNicol, M. W. (1970). Diuretics in acute myocardial infarction (abstract). Clinical Science, 38, 32p.

Tattersfield, A. E., McNicol, M. W., Shawdon, H., and Rolfe, D. (1969). Chest xray film in acute myocardial infarction. British Medical fournal, 3, 332.

Wolk, M. J., Scheidt, S., and Killip, T. (1972). Heart failure complicating acute myocardial infarction. Circulation, 45, I125.

World Health Organization Report (197I). Euro 820I (5). Ischaemic Heart Disease Registers. Copenhagen.

Requests for reprints to Dr. G. Sloman, Cardiac Department, Royal Melbourne Hospital, Victoria 3050, Australia. 